DOES INFORMATION UNDERMINE BRAND?

INFORMATION INTERMEDIARY USE

AND PREFERENCE FOR BRANDED WEB RETAILERS

Joel Waldfogel

Lu Chen

Working Paper 9942 
NBER WORKING PAPER SERIES

\title{
DOES INFORMATION UNDERMINE BRAND? INFORMATION INTERMEDIARY USE AND PREFERENCE FOR BRANDED WEB RETAILERS
}

\author{
Joel Waldfogel \\ Lu Chen \\ Working Paper 9942 \\ http://www.nber.org/papers/w9942 \\ NATIONAL BUREAU OF ECONOMIC RESEARCH \\ 1050 Massachusetts Avenue \\ Cambridge, MA 02138
}

August 2003

We are grateful to the Wharton e-Business Initiative (WeBI) for financial support. The views expressed herein are those of the authors and not necessarily those of the National Bureau of Economic Research.

(C)2003 by Joel Waldfogel and Lu Chen. All rights reserved. Short sections of text, not to exceed two paragraphs, may be quoted without explicit permission provided that full credit, including $(\mathrm{C}$ notice, is given to the source. 
Does Information Undermine Brand? Information Intermediary Use and Preference for Branded Web Retailers

Joel Waldfogel and Lu Chen

NBER Working Paper No. 9942

August 2003

JEL No. F1, N10, O1

\begin{abstract}
Investments in brand provide one method for vendors to become known and convince potential customers that vendors will deliver as promised. Alternatively, third-party information on retailers' existence, as well as whether they tend to keep their commitments can serve a similar function and may undermine investments in brand. This study uses a 13-month panel dataset on 1998-99 Internet shopping behavior and use of information intermediaries by over 30,000 households to examine whether information use undermines brand. We find that individuals who take up using price comparison sites reduce their shopping at a broad group of branded retailers by about a tenth. Users of pure price comparison sites, such as DealTime and mySimon, also reduce their Amazon use by about a tenth, while individuals using BizRate, which provides both price comparison and vendor reliability information, reduce their Amazon shopping by a fifth. The results have possible implications for both firm strategy and the evolution of market structure. If information weakens the pull of brand, then Internet retailing may grow less concentrated over time.
\end{abstract}

Joel Waldfogel

The Wharton School

University of Pennsylvania

3100 Steinberg-Dietrich Hall

Philadelphia, PA 19104-6372

and NBER

waldfogj@wharton.upenn.edu

\section{Lu Chen}

The Wharton School

University of Pennsylvania

3100 Steinberg-Dietrich Hall

Philadelphia, PA 19104-6372 
Transactions are easier for sellers to consummate when customers are aware of sellers and, moreover, have confidence that sellers will deliver as promised. Seller reputation, or brand, is one means by which firms have traditionally both promoted buyer awareness and bonded their promises to deliver (Klein and Leffler, 1981). Firms' nonrecoverable investments in brand capital, foregone if they renege, can convince consumers that sellers will deliver as promised. Consumer goods firms spend roughly $\$ 88$ billion per year on advertising targeted at consumers. ${ }^{1}$ Amazon.com itself spent $\$ 90$ million in the fourth quarter of 1999 creating and maintaining its online retail brand. ${ }^{2}$ At the same time, information provision, by sellers or by third parties, is an alternative mechanism for making consumers willing to undertake transactions. The availability of information on retailers existence and reliability can make customers willing to patronize lesser-known, rather than branded, retailers. In so doing, information can undermine investments in brand and make markets more competitive.

The effect of information on the potency of brand has implications for market structure as well as firm strategy. The ability of firms to convince consumers to shop at particular vendors can promote industrial concentration. Advertising is generally viewed as one of the endogenous sunk costs with which firms attract market share, keeping industries concentrated (Sutton, 1991). A large number of firms entered Internet retailing between 1997 and 1999, indicating that the exogenous fixed (sunk) entry costs are not too high. Yet, by 2000 the majority had exited, unable to attract sufficient numbers of customers for viability. It is possible that consumers who are uncertain about vendors favor vendors with recognizable names. Indeed, Smith and Brynjolfson (2001) document

\footnotetext{
${ }^{1}$ See 1999 total at the Advertising Age website, http://www.adage.com/page.cms?pageId=476.

${ }^{2}$ See Wollenberg (2000).
} 
that in 1999, customers were willing to pay a premium for books from well-known retailers. Equipped with knowledge about vendors' existence and reliability, customers might grow less easily gulled by advertising and, in turn, less loyal to branded retailers.

The question of whether information obviates brand is not new, but Internet retailing provides an auspicious testing ground. The retail landscape on the Internet includes both branded sellers such as Amazon, unbranded competitors, third-party information providers (“information intermediaries"); and, perhaps most important, datasets allowing researchers to directly observe both shopping and II use behavior for the same individuals. The late 1990s saw the appearance of information intermediaries such as DealTime and mySimon, providing price and delivery information, and others, notably BizRate, offering vendor reliability information as well. The use of II sites has increased rapidly over the past few years makes it possible to measure their effect of consumers' choice of branded or unbranded retailers. This is the study's goal.

In this study we make use of a 13-month Media Metrix panel data set on over 30,000 households in between December 1998 and December 1999, a period shortly after information intermediaries first appeared. ${ }^{3}$ The novelty of information intermediates makes this period attractive for study because the growth in their use reflects a change in information supply rather than information demand. The data indicate each page visited by each household. We use the data to create monthly measures of II use as well as the tendency to shop at branded, as opposed to unbranded, retailers. The sample includes persons who never visit an II (during the sample period), as well as persons who begin

\footnotetext{
${ }^{3}$ BizRate was founded in 1996 but secured major funding in April 1998 (see Weintraub, 2000). MySimon was founded in April 1998 (PR Newswire, 1999a). Dealtime was founded in 1997 (PR Newswire, 1999b).
} 
visiting II sites during the sample period. We can thus use panel data approaches to ask how use of II sites relates to the choice of branded vs unbranded retail sites.

We find that when individuals use information intermediaries, they reduce their shopping at branded vendors by substantial and statistically significant amounts.

Individuals using any of the three II sites in the study reduce their use of branded retailers by about 10 percent. Use of BizRate, which provides survey-based vendor reliability information as well as price comparison, has no additional effect on the tendency to use branded sites overall, although its use reduces Amazon shopping by about a fifth.

The paper proceeds in three sections. First we discuss the theoretical background, as well as the relevant existing literature. Second, we describe the data used in the study. Our data discussion also includes our discussion of our measures of II use and branded site choice. Third, we present results on the relationship between II use and branded site choice. A brief conclusion follows.

\section{Background}

\section{Theoretical Background}

Does information make markets more competitive? With Stigler (1961) as theoretical motivation, empirical studies of the effects of regulatory changes reducing search costs, such as permitting price advertising or mandating disclosure of quality information, generally find that reductions in information costs make markets more competitive. $^{4}$ Among other things, the Internet provides a technology for low-cost

\footnotetext{
${ }^{4}$ A number of studies examine the effect of the permissibility of price advertising on prices. Benham (1972) and Kwoka (1984) find that price advertis ing reduces prices, while Milyo and Waldfogel (1999) find no effect. Studies of the effects of mandatory information disclosure find less ambiguous effects of information on market competitiveness. See Devine and Marion (1979) or Jin and Leslie (in press).
} 
information search, and a number of recent studies ask whether the Internet ushers in a world of "frictionless commerce."

Empirical studies of the effect of the Internet generally find that it makes markets more competitive. Brown and Goolsbee (2002) find that the growing availability of life insurance price information online induces insurers to charge lower prices to customers of the sort likely to use the Internet. Ellison and Ellison (2000) find that customers patronizing Pricewatch ( a specialized computer component price comparison site) are exceedingly price elastic, to the point of raising concerns about a 'Bertrand Paradox.' In other words, this information-rich market is very competitive.

On the other hand, Smith and Brynjolfson (SB, 2001) find that visitors to the EvenBetter book price comparison site in 1999 were willing to pay a premium to buy from branded retailers. ${ }^{6}$ Goolsbee and Chevalier (2002) present evidence that Barnes \& Noble and, especially, Amazon have fairly inelastic demand and, one can infer, rather powerful brands. In contrast to the Pricewatch context, the book context has buyers who are not technically savvy and, perhaps as a result, it also has powerfully branded sellers. The continued potency of brand in the face of price comparison information suggests that customers lack faith that unfamiliar retailers will deliver as promised.

Two points bear discussion about the finding that customers are willing to pay for brand. First, while brand matters among site users, their use of the price comparison site may reduce how much brand matters. Even if brand still matters, the Internet may nonetheless make markets more competitive if consumers care less about brand after

\footnotetext{
${ }^{5}$ The term is borrowed from Brynjolffson and Smith (2000).

${ }^{6}$ Based on a sample of visitors to the book-shopping site EvenBetter.com (which later became part of DealTime), they estimate a vendor choice model based on consumer's decision of which site to click through to. They find that EvenBetter users are willing to pay a premium for Amazon, Barnes \& Noble, and Borders relative to other book vendors.
} 
getting access to price comparison information than they did before. The SB study, based only on behavior of visitors to a price comparison, cannot speak to this point.

Second, price comparison information alone may be inadequate to overcome the pull of brand. Brand may do more that hold customers' attention; it may also serve as a commitment device, as in Klein and Leffler (1981). Hence, information on vendor reliability may complement price comparison information to overcome brand. BizRate's provision of vendor reliability information may allow consumers to resist the pull of brand even if product information alone does not.

In this study we ask whether the use of II sites undermines brand. Because we include both price comparison sites (DealTime and mySimon) as well as the BizRate site providing vendor reliability information as well, we shed light on two questions. First, we can determine whether use of price comparison information lessens the pull of brand. Second, we can determine whether information on vendor reliability affects the preference for branded retailers beyond the price comparison information alone.

\section{Information Intermediaries}

Information intermediaries are shopping comparison sites that display prices and other product attributes (shipping costs and times) and in some cases vendor reliability information from a variety of sellers. II sites typically comb the web with automated 'bots' to find the prices and other characteristics of items on offer. ${ }^{7}$ Different II sites

\footnotetext{
${ }^{7}$ For example, "mySimon uses Virtual Agent ${ }^{\mathrm{TM}}$ technology to create "intelligent agents" trained by the company's team of shopping experts to collect information from virtually every online store. The result is the best product and pricing information across the Web." From http://www.cnet.com/aboutcnet/0-136127-7286780.html accessed December 19, 2002.
} 
include different vendors, and in some cases II sites accept compensation to present particular vendors' information favorably (see Jones, 1999).

In addition to product characteristics gleaned from automated web surfing, some II sites also provide vendor reliability information based on shopper surveys. In particular, BizRate surveys shoppers about their experiences with each vendor and reports this information at their site. BizRate undertakes large-scale surveys of shoppers to get information about their experience with the online vendors they have used.

BizRate seeks to provide unbiased information, and "Consumer Reports' online magazine has chosen to supplement its ratings with Bizrate's information because of its high standards for gathering shopping data" (see Jones, 1999).

Business models vary across II sites. Some accept "pay for placement," in which sellers pay for favorably portrayal. For example, at DealTime, "results include stores that pay us for making their offering more visible (e.g. color logos or preferred placements), as well as stores that pay us nothing. Our mission is to bring you search results that are specific to what you have requested, and offering only what you want - nothing more, and nothing less." ${ }^{\prime 8}$ Others, such as BizRate, generates revenue by selling market research and from fees generated when users click through from BizRate and make a purchase (Weintraub, 2000).

\section{Data}

The basic data underlying this study the web pages visited by about 30,000 Media Metrix (MM) households between Dec '98 and Dec '99 visiting certain retail sites. We

\footnotetext{
${ }^{8}$ See http://www.dealtime.com/dealtime2000/Pages/About/0,2751,2063,00.html? mode=c\&CG=1\&DCG=1 accessed December 17, 2002.
} 
know the domain for each page and the sequence in which pages are viewed. There are a total of over 22 million retail page visits in the sample. The number of households in the panel fluctuates somewhat month-to-month. Nearly two thirds of households are in the sample for at least 3 months over the 13-month period; roughly a third are in the sample for 6 months or more. Media Metrix collects data from persons who agree to install MM monitoring software on their computers. MM aims to produce a sample representative of Internet-connected households, and the sample characteristics are similar to those of the CPS Computer and Internet Supplement. ${ }^{9}$

Our goal is to use the MM data to create measures of the use of II sites, as well as the tendency to visit branded and unbranded retailers, by month for each household. The first task is simple: given a list of II domain names we can calculate the number of pages visited at each II by each household in each month. The second task is slightly harder. We describe them in turn.

\section{Quantifying II Use}

We searched contemporary journalistic accounts of price comparison sites and found four that appeared frequently in our data: BizRate, Dealtime, MySimon, and Pricescan. We calculate the number of pages viewed at each site by each household in each month. Table 1 shows how the tendency to visit II sites varies across the II sites in our sample. By the end of the sample period, 18.5 percent of households had visited BizRate, followed by 6.5 percent at Dealtime, 5.9 percent at MySimon, and 4.3 percent at Pricescan. In this study we focus on the top three of these.

\footnotetext{
${ }^{9}$ Sinai and Waldfogel (2001) document that the distributions of education and race are similar across MM and CPS Internet user samples.
} 
Tables 2a-c shows how the tendency to visit each of the three II sites evolves throughout the sample. In table 2a, on BizRate, the first column shows the share of households visiting the II in each month, and it grows from 1.3 percent in Dec. 1998 to 9.1 percent in Dec. 1999. The second column shows how the share that has ever visited (during the sample period) grows over time, from 1.3 percent for the persons in the sample during the first month to 18.5 percent of the persons in the sample during the last month. The third column shows the number of BizRate pages per month (among both users and nonusers). The final column shows the cumulative number of BizRate pages visited in each month, and it totals just over 3 by the end of the sample. Because many persons view no pages, it is useful to examine use among users, in the bottom panel. The median number of pages viewed by persons visiting BizRate during the month increases from 3 to 6 over the sample. The mean and $75^{\text {th }}$ percentile increase sharply as well. It is clear from the table that BizRate use is increasing over time, suggesting the promise of an empirical strategy based on within household variation in II use and the tendency to visit branded sites.

Tables $2 b$ and $2 c$ repeat this exercise for MySimon and Dealtime. Use incidence is much lower, but the trends are quite similar. While there are 4,816 household-months with a BizRate visit, there are only 1,046 and 1,253 household-months with MySimon and Dealtime visits, respectively. Among households in the sample during the last month, roughly six percent had visited each of MySimon and Dealtime (compared with nearly 19 percent for BizRate). While we proceed with analyses of all three II sites, the BizRate context appears to offer the greatest promise of identification. 
Tables 2a-c show that the sample covers a period when II sites were gaining widespread use. Takeup of II use is therefore reasonably viewed as a response to newly available supply rather than a change in consumers' appetite for information about vendors. This interpretation is important because our empirical approach will attempt to draw inferences about the effect of II use from within-individual variation II use and patronage of branded retailers over time.

\section{Measuring Preference for Branded Sites}

The empirical question at the heart of our study is whether visitors to II sites, armed with price and/or reliability information about various branded and unbranded vendors, are more likely than their uninformed counterparts to choose the unbranded alternatives. To implement this approach one needs a list of the set of vendors a shopper might conceivably visit when shopping for some item - the "choice set" - and a way to classify whether the vendors are branded. The share of page visits to branded sites, among the page visits to all sites in the set, would provide a measure of the preference for branded sites. Assuming one could determine which sites were branded, this strategy would be simple in a world with single-product retailers and single-product IIs. One would simply assemble a list of all vendors in some category, say apples, and classify a subset as branded. The share of apple page visits to branded apple sites would then provide a measure of the preference for brandedness (in apples). One could easily calculate this measure for individuals both before and after they had visited the apple II, compared to the pattern for other individuals not visiting an II. 
Reality has the complication that each II covers its own idiosyncratic subset of products, giving rise to a danger of confusing an informative effect of II use with a product composition effect. To see this, suppose that the retail sector includes two products, apple and oranges, and that shoppers have a stronger preference for branded vendors in oranges than in apples. Suppose further that the II covers only apple vendors. If we use the branded share of overall (apple and orange) retail page visits as our measure of the preference for brandedness, then we may mistakenly attribute to II use the intent to buy apples rather than the preference for brandedness. That is, II use may be associated with the desire to buy apples - in which consumers have no preference for brand - rather than a willingness to use less known vendors. We will refer to this phenomenon, which comes up again, as "bundle intent." The solution to this problem is to define a choice set appropriate to the retail categories that the II covers. In our hypothetical example, it is apple vendors rather than apple and orange vendors.

Visiting a particular II provides a shopper with information about vendors in a specific set of retail categories. To construct an accurate test of the effect of the II requires a measure of shoppers' use of branded vendors when shopping for those items. The relevant choice set is therefore page visits to sites selling items covered by that II. We do not observe this directly, but we can approximate it from the set of retail sites viewed immediately after leaving the II site. In our sample, the top five retail sites visited immediately after leaving BizRate are Buy, ShopTLC, Egghead, 800, and Amazon. Suppose that, for illustration, one treated Amazon and Egghead as branded, and the others as unbranded, then for each month of the sample one could calculate an 
individual's preference for brandedness when shopping for BizRate-listed items as the combined Amazon and Egghead share of page visits to all five of these sites.

The actual situation is slightly more complicated that this example. First, some of the sites visited immediately after leaving an II are not retail sites at all. A user can surf from BizRate to CNN.COM simply by clicking a favorite in the browser. Since MM includes a site type designation that indicates whether a site is retail, we can exclude hits to non-retail sites. However, some sites that are classified as retail should also be excluded. Chief among these are auction sites which in general do not sell the (new) items listed at II sites. Ebay alone receives a large fraction of retail page hits in our sample. In our baseline analyses below, we exclude auction sites from the choice sets. ${ }^{10}$ Second, there are many more than five sites visited immediately after leaving BizRate. Some of these sites are visited frequently, others only once. It is not immediately obvious whether we should include all of the non-auction retail sites visited immediately after leaving an II - for example, 256 sites are visited immediately after leaving BizRate - or alternatively whether we should use a cutoff (including sites visited at least $x$ times upon leaving an II). Our solution is to run everything with three cutoffs: 10,5 , and 0. We report only results based on the cutoff of 5 , but all the other cutoffs give substantively similar results. Table 3 lists the retail sites visited on at least 5 occasions in the sample immediately after leaving each of our three IIs.

\footnotetext{
${ }^{10} \mathrm{We}$ also handchecked each of the sites included in the choice sets to determine whether they are actually retailers. On this basis we excluded a number of sites in coupon categories (such as MYPOINTS) as well as a few stray sites. Because we are searching in 2002 while trying to determine site function in 1999, in many cases we conducted Google searches for pages containing site names. These hits often contained user descriptions of sites from roughly the same time periods. In other instances, we found that the 1999 page names were now part of another retailer, which we took to indicate that the sample site was a retailer in 1999.
} 
Third, it is not clear how to draw the line between branded and unbranded sites. A glance at table 3 shows Amazon among a number of other familiar, and presumably "branded," names. The familiar names fall into four categories, offline retailers predating the web (such as WalMart), catalog retailers predating the web (Fingergut), manufacturers (such as Hanes), and other known entities (such as CDNow). These categories, particularly the last, are not precisely defined. However, we can use various combinations of these categories of retailers to calculate different measures of the branded retail page visits, varying from the minimal (Amazon only) to the more inclusive (all of the above). ${ }^{11}$

Table 4 provides elements of various measures of the tendency to visit branded retailers. Each column corresponds to the choice set of a different II. The first entry in the BizRate column shows the average number of Amazon pages viewed per month by each household. We view this as a minimal measure of the number of branded page visits. Subsequent rows in this column show the numbers of pages visited at the other known retailers with at least 5 post-II page visits in the II's choice set. For example, catalog retailers in the BizRate choice set attract 2.57 monthly page visits per household. Because different offline chains and catalog retailers appear in the different choice sets, the number of pages differs across columns. Sites in the BizRate choice set collectively attract an average of 34.01 page visits per household- month. Of these, 23.42 (68.9 percent) are to known sites. Over a fifth (22.2 percent) are to Amazon alone. Columns (2) and (3) repeat the exercise for DealTime and mySimon.

\footnotetext{
${ }^{11}$ Our minimal definition - Amazon alone - has some justification. First, SB (2001) use a similar definition, Amazon and Barnes \& Noble, as their branded sites. In our case, Barnes \& Noble does not appear sufficiently frequently in all of the choice sets. Second, Lohr (1999) refers to Amazon and eBay as the leading online brands in 1999.
} 
Users visit an average of 55 additional pages at other sites classified as retail by MM (excluding auctions). If we treat all non-auction MM retail as the denominator, then Amazon alone makes up 8 percent, while the "total known" sites make up 26 percent. Visits to auctions add another 61 pages to the total. If we include these in the denominator as well, then Amazon visits make up 5 percent, while visits to total known retailers make up 16 percent. We view the II choice set as the most sensible denominator. We will also report results below using the non-auction and total MM retail category, to explore whether our results depend on how we defined the denominator.

\section{Results}

This section presents regression evidence about 1) who uses II sites, and 2) the relationship between II use and branded site choice.

\section{Who Uses II Sites?}

Table 5 provides information about the use of II sites, by education, race, age, and income of household heads. The use measure is whether the household ever uses during the sample period. BizRate use increases in education, from roughly 16 percent of persons without college degrees to about 19 percent for households headed by persons with college degrees, while DealTime use declines in education. II use is highest among Asians, followed by whites, then blacks (except for DealTime, which is used by 9 percent of sample blacks, compared with 6 percent of sample whites). There is no clear pattern in age for BizRate and mySimon. DealTime use, on the other hand, clearly declines in age. 
There is a fairly clear pattern of increasing use of BizRate and mySimon as household income is higher, while DealTime use declines in income.

\section{Effect of II Use on Preference for Branded Retailers}

Does II use affect consumers' preference for branded retailers? One strategy would be to compare visitors to II sites against shoppers not visiting the II sites to see which group is more likely to opt for branded vendors. An obvious problem with this strategy is that II users may differ from non-II users in their tendency to use branded sellers for reasons entirely apart from II use per se. For example, bargain-conscious persons may be more likely to use II sites and less likely to shop at branded retailers. An empirical strategy that can surmount this problem is to look within shopper at the tendency to use branded sites before and after visiting II sites. Such a strategy has particular appeal during our sample period as consumers begin using II sites shortly after their initial appearance. In particular, then, one can ask whether persons are more likely to opt for the unbranded sites after visiting an II than they were before. This approach controls for any fixed unobserved attribute, such as bargain-consciousness, determining the tendency to use branded sites.

It is helpful to define the following notation.

$B_{h t}^{c}=$ branded page visits as a percent of total page visits to sites in the choice set for II $c$ by household $h$ in month $t$; $I I_{h t}=$ II pages visits in month $t$ by household $h$, $\delta\left(I I_{h t}\right)=$ whether household h visits an II this month (the function $\delta(x)$ is 1 when $x>0,0$ otherwise). 
$c\left(I I_{h t}\right)=\sum_{j=0}^{t} I I_{h j}$ or the sum of II pages ever visited (during the sample period),

$\delta\left(c\left(I I_{h t}\right)\right)=$ whether household $h$ has ever visited an II as of month $t$.

Our basic regression approach is

$B_{h t}^{c}=\alpha I n f o_{-} \operatorname{Int}_{h t}+\gamma_{t}+\mu_{h}+\varepsilon_{h t}$,

where $B_{h t}^{c}$ is one of the measures of branded site use as a share of all retail sites use, Info_Int is one of our measures of II use, $\gamma_{t}$ is a month-specific effect, and $\mu_{h}$ is a household-specific fixed effect. All regressions include both month dummies and household fixed effects. This model allows the tendency to visit branded sites to vary arbitrarily across households and over time. The samples for each II include households with page hits in their II choice sets in each month. The BizRate sample includes 101,710 household month observations, while the DealTime and mySimon samples include 67,651 and 84,219 observations respectively. ${ }^{12}$

It is not clear a priori how best to measure the tendency to use II sites, so we experiment with all four. The first row of table 6 describes BizRate results. The first four columns use the minimal measure of branded site use, Amazon pages/page visits in BizRate choice set. Within these four columns, the first uses BizRate pages visited this month as the measure of II use, the second uses cumulative BizRate pages, the third uses a dummy for whether the household visits BizRate this month, and the fourth uses a dummy for whether the household has visited BizRate ever (during the sample, as of the current month). Columns 5-8 repeat this pattern using a more expansive measure of the preference for branded sites as the dependent variable (all page visits to "known" sites/

\footnotetext{
${ }^{12}$ Sample sizes differ because the choice sets - and consequently the number of observations with pages visits to sites in the choice set in a month-differ as well.
} 
page visits in BizRate choice set). In all eight specifications the measure of II use has a negative and significant coefficient. When all four measures of BizRate use are included simultaneously (not reported), the binary contemporaneous measure (visit this month) retains significance with both dependent variables, and the "ever visit" measure retains significance with the "known" numerator. The continuous measures are insignificant.

To get a feel for orders of magnitude, note that the average ratio of Amazon page visits to total BizRate choice set page visits is 0.22 . Those who visit BizRate reduce their Amazon share by 4 percentage points, or about a quarter (see column 3). "Known" sites make up roughly 70 percent of page visits to sites in the BizRate choice set. Those who visit BizRate reduce their "known" share by about 6 percentage points, or about a tenth (see column 7).

The next two rows of table 6 repeat the exercise in the first row for DealTime and mySimon. Results are similar in direction and magnitude, although few results are statistically significant for mySimon.

Because the column (7) coefficient is only slightly larger than the column (3) coefficient for BizRate, we can conclude that most of the reduction is in Amazon shopping rather than shopping at other known sites, and a direct decomposition confirms this. Our total known category has up to 5 constituent parts: Amazon, offline chains, manufacturers, catalog stores, and other known vendors. We decompose the overall known effects (from column 7 of table 6) into these constituent parts in table 7 . The first column shows coefficient on a visit this month dummy from a regression with the constituent part (Amazon, catalog retailer, etc) as the dependent variable. The second column shows the constituent part's share of the BizRate choice set, and the third column 
shows the proportionate reduction in use of the constituent part. For example, the first row of column (3) shows that BizRate use brings about a 19 percent reduction in Amazon use $(-0.0423 / 0.22=-19.1 \%)$. BizRate use also reduces patronage of offline chains by a similarly large 18 percent.

Columns (4)-(6) of table 7 repeat the decomposition exercise for DealTime. While the Amazon coefficient in the DealTime regression is roughly the same size as the corresponding coefficient in the BizRate regression, Amazon makes up a much larger share of the shopping among elements of the DealTime choice set (45 percent rather than 22 percent). Hence, as table 7 shows, DealTime use brings about a smaller proportional reduction in Amazon use (9.4 percent). Other elements are either small or have insignificant reductions. Columns (6)-(9) perform the decomposition exercise for mySimon. While the overall "total known" effect is significant, none of the individual elements are significant.

The basic results of the study are now established: II use reduces the tendency to choose branded retailers by roughly a tenth. While the overall effect is about the same size for BizRate as for DealTime or mySimon, the effect of BizRate on Amazon is roughly twice as large as the effect of the other II's on Amazon. How big are the measured effects? Among the shopping at sites in the choice sets, about three quarters of page visits are to known sites. During the last period of the sample, nearly 10 percent of individuals use BizRate, leading to a roughly one percent $(0.10 *(-0.064 / 0.69=-0.9 \%)$ reduction in use of known sites generally. In particular, BizRate users in the sample reduce their Amazon shopping by roughly 2 percent $(0.10 *(-0.0423 / 0.22)=-1.9 \%)$. The next section of the paper is devoted to assessing the robustness of this result. 


\section{Robustness}

In this section we explore the robustness of our result to a number of concerns, including possible aut ocorrelation of the errors across months, the use of different denominators other than the choice sets, the possibility that the result is explained by the volume of retail pages viewed, and the way we control for the time pattern of branded shopping. To avoid proliferation of results, we use just one of the four specifications in table 6 as baselines for robustness analysis. In particular, we build on the specification with the dummy for whether the person visits the II this month.

The first two entries in the top tow of table 8 show how the coefficients on "visit BizRate this month" vary when one adjusts for possible first-order autocorrelation of the errors within cross sectional units. ${ }^{13}$ This adjustment has a fairly negligible effect on the size and significance of the coefficient of interest. The same can be said for the analogous entries for the other two II sites.

The next two columns replace the denominators of our baseline measures of preference for branded retailers - the page visits to retail sites in the choice set - with a more inclusive measure, all non-auction retail page visits. This measure inflates the denominator substantially (and includes many vendors and items in the denominator that are not included in the numerator). Still, in regressions with this denominator, visits to BizRate this month are associated with a reduction in the tendency to visit Amazon relative to all retail, but BizRate use is not associated with reductions in the use of all known sites relative to all retail. Indeed, these results suggest that II use is associated with increases in the tendency to use non-Amazon retail sites. We suspect this is an

\footnotetext{
${ }^{13}$ See Baltagi and Wu (1999).
} 
artefact of the measurement approach. Use of an II, say BizRate, indicates "bundle intent," the impulse to shop for the mix of items listed at BizRate. If the BizRate items are not entirely representative of retail generally, then a positive relationship between BizRate use and the tendency to shop at the known sites on BizRate, relative to other retail sites, may simply reflect the impulse to shop to items listed there.

The next two columns employ a denominator that includes auction site page visits. Results are similar to those in columns (3) and (4). Auction sites, by including used items, cover different items than the new goods covered at the II sites, so we expect the "bundle intent" problem to bias the approach even farther from finding negative effects of II use on the preference for branded retail.

The last two columns show the visit this month coefficients from specifications including the number of retail non-auction pages viewed this month as an explanatory variable. It is possible that the volume of shopping relates to both II use and the tendency to visit branded retailers. If so, then the coefficient on visit this month would be spurious. Inclusion of a retail page volume variable has virtually no effect on the coefficients, for any of the three II sites.

The basic specifications allow an arbitrary time pattern of branded site use, but they impose the same pattern on all kinds of users. We can relax this restriction. When we interact the month dummies with dummies for education, race, age, or income (thereby allowing the time pattern to vary by these characteristics), the results for all three II sites change only negligibly (not reported). 


\section{Conclusion}

Firms spend a great deal on advertising to create familiarity and trust with consumers. Yet, consumers can get information about firms from other sources as well, and it is possible that information can undermine brand. The Internet retailing context provides an auspicious context for testing this because it includes branded and unbranded retailers, information intermediaries, and - most important - the possibility of observing shopping and information use for the same persons.

Using panel data on shopping at branded and unbranded retailers and the use of information intermediaries by over 30,000 online households, we find that consumers' information use weakens the pull of brand. These results are robust to a number of specifications for dealing with alternative hypotheses. Use of any of the three II sites reduces use of known sites by about a tenth. The effect of BizRate falls disproportionately on Amazon and offline chains, whose use falls about a fifth. The results indicate that information helps to overcome the pull of brand.

If the results of the study are correct, they have possible implications for both firm strategy and market structure. First, if investments in brand are affected by information available from third parties, managers may want to focus attention on this vulnerability. Well-known firms might find advantage in obfuscating the information provided by third parties, while less known firms might want such information widely available. Second, while retailing on the Internet has grown quite concentrated over the past few years, it is not clear that this trend will continue indefinitely. If information undermines the effectiveness of advertising in attracting market share, then the future of Internet retailing may be less concentrated that current analysts expect. 
The study has a number of weaknesses that should be mentioned. First, we share the weakness with other studies that we do not observe actual buying behavior, only page visits. It is possible that shopping behavior does not accurately represent buying behavior. Second, while our empirical strategy effectively deals with fixed attributes affecting preference for branded retail and the tendency to use II sites, our approach is undermined by factors simultaneously changing both of these as II sites came into use. These concerns aside, this study provides evidence that information use undermines the pull of brand. 


\section{References}

Baltagi, Badi H; Wu, Ping X. Unequally Spaced Panel Data Regressions with AR(1) Disturbances. Econometric Theory. Vol. 15 (6). p 814-23. December 1999.

Brown, Jeffrey R; Goolsbee, Austan. Does the Internet Make Markets More Competitive? Evidence from the Life Insurance Industry. Journal of Political Economy. Vol. 110 (3). p 481-507. June 2002.

Brynjolfsson, Erik; Smith, Michael D. "Frictionless Commerce? A Comparison of Internet and Conventional Retailers." Management Science. 46, pp. 563-585. 2000.

Clay, Karen, et al. Retail Strategies on the Web: Price and Non-price Competition in the Online Book Industry. Journal of Industrial Economics. Vol. 50 (3). p 351 -67. September 2002.

Devine, D Grant; Marion, Bruce W. The Influence of Consumer Price Information on Retail Pricing and Consumer Behavior. American Journal of Agricultural Economics. Vol. 61 (2). p 228-37. May 1979.

Ellison, Glenn and Sara Fisher Ellison. "Search, Obfuscation, and Price Elasticies on the Internet.” MIT Working paper, June 2001.

Goolsbee, Austan and Judy Chevalier. "Measuring Prices and Price Competition Online: Amazon and Barnes and Noble." University of Chicago Working Paper. November 2002.

Jin, Ginger and Phillip Leslie. "The Effect of Information on Product Quality: Evidence from Restaurants Hygiene Grade Cards,"forthcoming the Quarterly Journal of Economics.

Klein, Benjamin; Leffler, Keith B. The Role of Market Forces in Assuring Contractual Performance. Journal of Political Economy. Vol. 89 (4). p 615-41. Aug. 1981.

Kwoka, John E, Jr. Advertising and the Price and Quality of Optometric Services. American Economic Review. Vol. 74 (1). p 211-16. March 1984.

Milyo, Jeffrey; Waldfogel, Joel. The Effect of Price Advertising on Prices: Evidence in the Wake of 44 Liquormart. American Economic Review. Vol. 89 (5). p 1081-96. December 1999.

PR Newswire, "mySimon Tops 1200 Merchant Mark to Find the Web's Best Deals." January 19, 1999.

PR Newswire, “DealTime.com Personal Online Shopping Service Debuts.” February 9, 1999. 
Smith, Michael D; Brynjolfsson, Erik. Consumer Decision-Making at an Internet Shopbot: Brand Still Matters. Journal of Industrial Economics. Vol. 49 (4). p 541-58. December 2001.

George J. Stigler "The Economics of Information." The Journal of Political Economy, Vol. 69, No. 3. (Jun., 1961), pp. 213-225.

Sutton, John. Sunk Costs and Market Structure. Cambridge: MIT Press. 1991

Weintraub, Arlene. "BizRate's Farhad Mohit sees himself at the forefront of an e-tailing revolution.” Business Week. June 5, 2000. 
Table 1: Percent of Sample Ultimately Visiting Selected II Sites Dec 98- Dec99

\begin{tabular}{lc}
\hline II site & \% ultimately visiting \\
\hline BizRate & 18.5 \\
Dealtime & 6.5 \\
MySimon & 5.9 \\
Pricescan & 4.3 \\
\hline
\end{tabular}


Table 2a: BizRate Use

\begin{tabular}{|c|c|c|c|c|c|}
\hline & \multicolumn{2}{|c|}{ whether use BizRate } & \multicolumn{2}{|c|}{ Bizrate Pages Viewed } & \multirow{2}{*}{$\frac{\mathrm{N}}{\text { (hh-months) }}$} \\
\hline month & this month & \multirow{2}{*}{$\frac{\text { ever }}{0.012582}$} & this month & ever & \\
\hline Dec-98 & 0.012582 & & 0.061732 & 0.061732 & 10,173 \\
\hline Jan-99 & 0.012969 & 0.020563 & 0.073464 & 0.121843 & 11,720 \\
\hline Feb-99 & 0.010274 & 0.025558 & 0.05239 & 0.148425 & 11,777 \\
\hline Mar-99 & 0.012254 & 0.033178 & \multirow{2}{*}{$\begin{array}{r}0.07044 \\
0.066169\end{array}$} & 0.209153 & 11,996 \\
\hline Apr-99 & 0.013184 & 0.041211 & & 0.261277 & 12,060 \\
\hline May-99 & 0.015708 & 0.05105 & 0.074612 & \multirow{2}{*}{$\begin{array}{l}0.325764 \\
0.411712\end{array}$} & 11,714 \\
\hline Jun-99 & 0.020774 & 0.0625 & 0.108077 & & 11,168 \\
\hline Jul-99 & 0.029555 & 0.07693 & 0.13943 & 0.521558 & 11,504 \\
\hline Aug-99 & 0.041858 & 0.096542 & 0.249415 & 0.723893 & 11,539 \\
\hline Sep-99 & 0.046419 & 0.113674 & 0.242977 & 0.88893 & 10,750 \\
\hline Oct-99 & 0.047406 & 0.131127 & 0.413954 & 1.255635 & 11,180 \\
\hline Nov-99 & 0.071324 & 0.159214 & 0.99013 & 2.14282 & 11,651 \\
\hline Dec-99 & 0.091172 & 0.185322 & 1.248781 & 3.052988 & 11,078 \\
\hline Total & 0.032473 & 0.077244 & 0.289407 & 0.772787 & 148,310 \\
\hline & Pages Viewed & by Current & BizRate Users & & \\
\hline & mean $\quad 2$ & 5 th pct $\quad n$ & median 7 & $5 \mathrm{pct}$ & iting this month \\
\hline Dec-98 & 4.90625 & 2 & 3 & 6 & 128 \\
\hline Jan-99 & 5.664474 & 2 & 3 & 7 & 152 \\
\hline Feb-99 & 5.099174 & 2 & 3 & 7 & 121 \\
\hline Mar-99 & 5.748299 & 2 & 4 & 8 & 147 \\
\hline Apr-99 & 5.018868 & 2 & 3 & 7 & 159 \\
\hline May-99 & 4.75 & 2 & 3 & 6 & 184 \\
\hline Jun-99 & 5.202586 & 2 & 4 & 7 & 232 \\
\hline Jul-99 & 4.717647 & 2 & 3 & 6 & 340 \\
\hline Aug-99 & 5.958592 & 2 & 4 & 8 & 483 \\
\hline Sep-99 & 5.234469 & 2 & 3 & 6 & 499 \\
\hline Oct-99 & 8.732075 & 2 & 5 & 9 & 530 \\
\hline Nov-99 & 13.88207 & 2 & 6 & 15 & 831 \\
\hline Dec-99 & 13.69703 & 3 & 6 & 15 & 1,010 \\
\hline Total & 8.912375 & 2 & 4 & 9 & 4,816 \\
\hline
\end{tabular}


Table 2b: MySimon Use

\begin{tabular}{|c|c|c|c|c|c|}
\hline & \multicolumn{2}{|c|}{ whether use MySimon } & \multicolumn{2}{|c|}{ MySimon Pages Viewed } & \multirow{2}{*}{$\frac{\mathrm{N}}{\text { (hh-months) }}$} \\
\hline month & this month & ever & this month & ever & \\
\hline Dec-98 & 0.001671 & 0.001671 & 0.027131 & 0.027131 & 10,173 \\
\hline Jan-99 & 0.001707 & 0.002816 & 0.014079 & 0.033021 & 11,720 \\
\hline Feb-99 & 0.001444 & 0.003736 & 0.017662 & 0.052136 & \\
\hline Mar-99 & 0.002167 & 0.005168 & 0.046349 & 0.095532 & $\begin{array}{l}11,777 \\
11,996\end{array}$ \\
\hline Apr-99 & 0.001824 & 0.00597 & 0.025788 & 0.116086 & 12,060 \\
\hline May-99 & 0.00239 & 0.00717 & 0.037812 & 0.138272 & 11,716 \\
\hline Jun-99 & 0.003044 & 0.009132 & 0.051034 & 0.181216 & 11,169 \\
\hline Jul-99 & 0.005128 & 0.012256 & 0.111604 & 0.289961 & 11,505 \\
\hline Aug-99 & 0.005719 & 0.01473 & 0.07703 & 0.33524 & 11,541 \\
\hline Sep-99 & 0.004744 & 0.016093 & 0.120372 & 0.393023 & 10,750 \\
\hline Oct-99 & 0.007602 & 0.021195 & 0.150599 & 0.512073 & 11,182 \\
\hline Nov-99 & 0.016906 & 0.032524 & 0.377585 & 0.86304 & 11,653 \\
\hline Dec-99 & 0.038264 & 0.059291 & 0.783594 & 1.513853 & 11,081 \\
\hline Total & 0.007052 & 0.014637 & 0.139985 & 0.346912 & 148,323 \\
\hline & Pages Viewed & d by Current & MySimon Use & & \\
\hline & mean 2 & 25 th pct & median & $75 \mathrm{pct}$ & \# visiting this month \\
\hline Dec-98 & 16.23529 & 5 & 16 & 25 & $\begin{array}{ll}5 & 17\end{array}$ \\
\hline Jan-99 & 8.25 & 3.5 & 6.5 & 11 & 20 \\
\hline Feb-99 & 12.23529 & 5 & 9 & 12 & 17 \\
\hline Mar-99 & 21.38462 & 5 & 9 & 30 & 26 \\
\hline Apr-99 & 14.13636 & 4 & 9.5 & 18 & 22 \\
\hline May-99 & 15.82143 & 1 & 3.5 & 15 & 28 \\
\hline Jun-99 & 16.76471 & 2 & 9.5 & 19 & 34 \\
\hline Jul-99 & 21.76271 & 5 & 11 & 25 & 59 \\
\hline Aug-99 & 13.4697 & 2 & 5 & 16 & 66 \\
\hline Sep-99 & 25.37255 & 3 & 14 & 24 & 51 \\
\hline Oct-99 & 19.81176 & 3 & 10 & 21 & 85 \\
\hline Nov-99 & 22.33503 & 4 & 11 & 30 & 197 \\
\hline Dec-99 & 20.47877 & 2 & 9 & 24 & 424 \\
\hline Total & 19.8499 & 3 & 9 & 23 & 1,046 \\
\hline
\end{tabular}


Table 2c: Dealtime Use

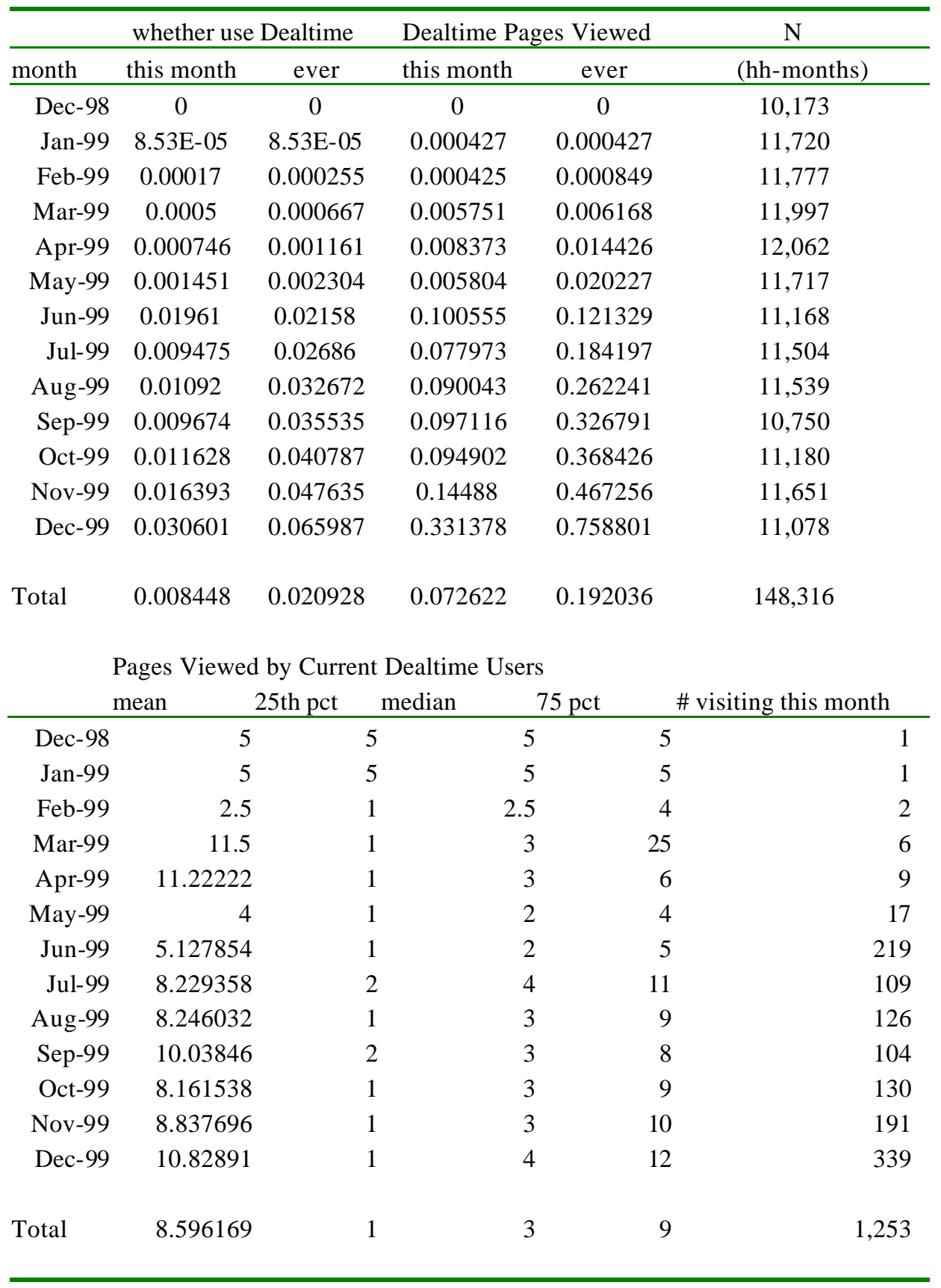


Table 3: Choice Set Elements for Information Intermediaries (includes domains with 10+ hits from some choice set)

\begin{tabular}{|c|c|c|c|c|}
\hline \multirow[b]{2}{*}{ Domain } & \multicolumn{4}{|c|}{ \# of hits in the choice set } \\
\hline & type & BizRate & Dealtime & Mysimon \\
\hline AMAZON & amazon & 141 & 15 & 148 \\
\hline BARNESANDNOBLE/BN & bn-chain & 30 & 3 & 15 \\
\hline CAMERAWORLD & catalog & 14 & & 1 \\
\hline CAMPMOR & catalog & 32 & & \\
\hline CHRISTIANBOOK & catalog & 16 & & \\
\hline CRUTCHFIELD & catalog & 32 & & 8 \\
\hline DOMESTICATIONS & catalog & 31 & & \\
\hline FINGERHUT & catalog & 49 & 6 & 5 \\
\hline INTMALE & catalog & 19 & & \\
\hline JANDR & catalog & 5 & 5 & 18 \\
\hline PCCONNECTION & catalog & 27 & 1 & \\
\hline SKYMALL & catalog & 4 & 13 & \\
\hline TOWERHOBBIES & catalog & 19 & & \\
\hline WAREHOUSE & catalog & 6 & 7 & 17 \\
\hline ZONES & catalog & 13 & 3 & 2 \\
\hline BESTBUY & chain & 10 & 2 & 24 \\
\hline CDWORLD & chain & 15 & & 5 \\
\hline COLDWATERCREEK & chain & 16 & & \\
\hline COMPUSANET & chain & 15 & & 3 \\
\hline JCPENNEY & chain & 34 & 1 & 6 \\
\hline MACYS & chain & 36 & 1 & 3 \\
\hline OFFICEDEPOT & chain & 12 & 2 & \\
\hline OFFICEMAX & chain & 7 & 1 & 11 \\
\hline SEARS & chain & 6 & & 12 \\
\hline SHARPERIMAGE & chain & 29 & 1 & 1 \\
\hline STAPLES & chain & 22 & & \\
\hline TOYSRUS & chain & 72 & 6 & 37 \\
\hline WAL-MART & chain & 15 & 2 & 22 \\
\hline CDNOW & known & 112 & 5 & 7 \\
\hline CDW & known & 18 & 1 & 6 \\
\hline EGGHEAD & known & 345 & 12 & 26 \\
\hline ETOYS & known & 67 & 4 & 38 \\
\hline KBKIDS & known & 23 & 23 & 3 \\
\hline KTEL & known & 22 & & \\
\hline QVC & known & 18 & 8 & 9 \\
\hline BMGMUSICSERVICE & $\mathrm{mfr}$ & 16 & & 4 \\
\hline BOOKSONTAPE & $\mathrm{mfr}$ & 15 & & \\
\hline DELL & $\mathrm{mfr}$ & 15 & 1 & 5 \\
\hline HICKORYFARMS & $\mathrm{mfr}$ & 11 & & \\
\hline OMAHASTEAKS & $\mathrm{mfr}$ & 10 & 1 & \\
\hline ONEHANESPLACE & $\mathrm{mfr}$ & 126 & & \\
\hline SHOPINTUIT & $\mathrm{mfr}$ & 36 & & \\
\hline 800 & unbr & 166 & & 40 \\
\hline
\end{tabular}




1800FLOWERS
ANDYSGARAGE
ARTUFRAME
AUDIOBOOKCLUB
BEYOND
BIGSTAR
BLUEFLY
BOTTOMDOLLAR
BRANDSFORLESS
BUY
CC-INC
CDPOINT
CDUNIVERSE
COMPGEEKS
COMPUTERS
COMPUTERS4SURE
DAMARK
DOWNLOAD
DRUGSTORE
DVDEXPRESS
EBAGS
ECOST
EVERYCD
FIRSTSOURCE
FOGDOG
FOOD
GEAR
GREATFOOD
HARDWARESTREET
HEALTHSHOP
IBABY
KILLERAPP
MCGLEN
MERCATA
MOTHERNATURE
MUSICBLVD
NETGROCER
NETMARKET
OUTPOST
OVERSTOCK
PCFLOWERS
PLANETRX
POWELLS
REEL
SHOP4

\begin{tabular}{|c|c|c|c|}
\hline unbr & 15 & & \\
\hline unbr & 15 & 1 & 2 \\
\hline unbr & 15 & & \\
\hline unbr & 47 & & \\
\hline unbr & 18 & & 29 \\
\hline unbr & 13 & & 2 \\
\hline unbr & 13 & & 14 \\
\hline unbr & & & 56 \\
\hline unbr & 11 & 12 & 2 \\
\hline unbr & 718 & 25 & 115 \\
\hline unbr & 54 & 8 & 12 \\
\hline unbr & & & 11 \\
\hline unbr & 15 & & 2 \\
\hline unbr & 18 & & \\
\hline unbr & 2 & & 11 \\
\hline unbr & 13 & 21 & 13 \\
\hline unbr & 30 & 1 & 5 \\
\hline unbr & 10 & & 1 \\
\hline unbr & 13 & & \\
\hline unbr & 24 & & \\
\hline unbr & 20 & & \\
\hline unbr & 28 & 15 & 37 \\
\hline unbr & 1 & & 15 \\
\hline unbr & 18 & 4 & 14 \\
\hline unbr & 13 & & 1 \\
\hline unbr & 29 & & 3 \\
\hline unbr & 15 & & \\
\hline unbr & 9 & & 10 \\
\hline unbr & 2 & 14 & 1 \\
\hline unbr & 109 & 1 & \\
\hline unbr & 16 & & 3 \\
\hline unbr & & & 47 \\
\hline unbr & & 1 & 11 \\
\hline unbr & 68 & 1 & 1 \\
\hline unbr & 16 & 3 & \\
\hline unbr & 13 & & 1 \\
\hline unbr & 14 & 1 & 1 \\
\hline unbr & 28 & 13 & 84 \\
\hline unbr & 28 & 8 & 8 \\
\hline unbr & 20 & 3 & 8 \\
\hline unbr & 17 & & \\
\hline unbr & 39 & & \\
\hline unbr & 18 & & \\
\hline unbr & 17 & & \\
\hline unbr & 12 & & 1 \\
\hline unbr & 21 & & 1 \\
\hline unbr & 35 & 2 & 7 \\
\hline unbr & 5 & 13 & 3 \\
\hline
\end{tabular}




\begin{tabular}{|c|c|c|c|c|}
\hline SHOPNOW & unbr & & 5 & 16 \\
\hline SHOPPING & unbr & & 14 & 30 \\
\hline SHOPTLC & unbr & 503 & & \\
\hline SMARTERKIDS & unbr & 52 & & 1 \\
\hline SUPREMEVIDEO & unbr & 7 & 3 & 24 \\
\hline TAVOLO & unbr & 68 & & 1 \\
\hline TOYSMART & unbr & 55 & 3 & 2 \\
\hline TOYTIME & unbr & 23 & & 5 \\
\hline VALUEAMERICA & unbr & & 13 & 58 \\
\hline VALUEPAY & unbr & & & 11 \\
\hline VIRTUALWORLD & unbr & 12 & 7 & \\
\hline
\end{tabular}


Table 4: Page Visits to Site Types, by Choice Set Elements with 5+ Visits

\begin{tabular}{|c|c|c|c|}
\hline type & $\begin{array}{l}\text { Biz Rate } \\
\text { pages }\end{array}$ & $\begin{array}{c}\text { Dealtime } \\
\text { pages }\end{array}$ & $\begin{array}{l}\text { MySimon } \\
\text { pages }\end{array}$ \\
\hline Amazon & 7.55 & 7.55 & 7.55 \\
\hline Barnes \& Noble & 1.48 & NA & 1.48 \\
\hline Catalogue & 2.57 & 0.68 & 1.11 \\
\hline Offline Chain & 2.81 & 0.38 & 1.87 \\
\hline Manufacturer & 2.52 & NA & 0.91 \\
\hline Other Known & 6.49 & 5.07 & 5.50 \\
\hline Total Known & 23.42 & 13.68 & 18.42 \\
\hline "Unbranded" & 10.59 & 2.99 & 5.39 \\
\hline Total this Choice Set & 34.01 & 16.67 & 23.81 \\
\hline Other MM Retail & 54.92 & 73.65 & 66.51 \\
\hline All MM Retail (excl auction) & 90.32 & 90.32 & 90.32 \\
\hline Auction & 60.59 & 60.59 & 60.59 \\
\hline \multirow[t]{2}{*}{ All Retail (incl auctions) } & 150.91 & 150.91 & 150.91 \\
\hline & $\%$ & $\%$ & $\%$ \\
\hline Amazon/Choice Set & $22.2 \%$ & $45.3 \%$ & $31.7 \%$ \\
\hline Amazon/ All MM Retail (excl auction) & $8.4 \%$ & $8.4 \%$ & $8.4 \%$ \\
\hline Amazon/ All Retail (incl auctions) & $5.0 \%$ & $5.0 \%$ & $5.0 \%$ \\
\hline Total Known/Choice Set & $68.9 \%$ & $82.1 \%$ & $77.4 \%$ \\
\hline Total Known /All MM Retail (excl auction) & $25.9 \%$ & $15.1 \%$ & $20.4 \%$ \\
\hline Total Known /All Retail (incl auctions) & $15.5 \%$ & $9.1 \%$ & $12.2 \%$ \\
\hline
\end{tabular}


Table 5: Who Uses II Sites?

\begin{tabular}{lcrrrrr}
\hline educ of head & $\begin{array}{c}\text { Ever use } \\
\text { BizRate? }\end{array}$ & \multicolumn{2}{c}{$\begin{array}{c}\text { Ever Use } \\
\text { MySimon? }\end{array}$} & \multicolumn{3}{c}{$\begin{array}{c}\text { Ever Use } \\
\text { DealTime? }\end{array}$} \\
\hline Grade school & $10.91 \%$ & 55 & $6.38 \%$ & 47 & $9.52 \%$ & 42 \\
Some high & $19.70 \%$ & 264 & $5.74 \%$ & 244 & $9.22 \%$ & 206 \\
High school & $16.00 \%$ & 2,163 & $3.93 \%$ & 2,012 & $6.40 \%$ & 1,687 \\
Some college & $16.33 \%$ & 4,108 & $3.72 \%$ & 3,793 & $6.55 \%$ & 3,296 \\
College & $19.44 \%$ & 4,640 & $4.72 \%$ & 4,284 & $7.11 \%$ & 3,743 \\
Post Graduate & $18.76 \%$ & 2,878 & $5.28 \%$ & 2,652 & $4.99 \%$ & 2,365 \\
Total & $17.86 \%$ & 14,108 & $4.44 \%$ & 13,032 & $6.45 \%$ & 11,339 \\
& & & & & & \\
Race & & & & & & \\
White & $17.97 \%$ & 12,874 & $4.53 \%$ & 11,893 & $6.39 \%$ & 10,368 \\
Black & $16.13 \%$ & 558 & $2.53 \%$ & 514 & $9.07 \%$ & 430 \\
Asian & $19.18 \%$ & 365 & $5.06 \%$ & 336 & $11.03 \%$ & 290 \\
Other & $16.70 \%$ & 473 & $3.20 \%$ & 437 & $4.56 \%$ & 373 \\
Total & $17.88 \%$ & 14,270 & $4.42 \%$ & 13,180 & $6.54 \%$ & 11,461
\end{tabular}

age deciles

\begin{tabular}{lrrrrrrr} 
& To 28 & $13.33 \%$ & 1,043 & $4.18 \%$ & 934 & $7.65 \%$ & 797 \\
& To 32 & $17.37 \%$ & 1,255 & $4.62 \%$ & 1,126 & $8.48 \%$ & 967 \\
& To 36 & $19.90 \%$ & 1,397 & $4.37 \%$ & 1,281 & $8.30 \%$ & 1,109 \\
& To 40 & $17.94 \%$ & 1,377 & $4.88 \%$ & 1,249 & $8.03 \%$ & 1,084 \\
& To 44 & $16.83 \%$ & 1,563 & $4.47 \%$ & 1,455 & $8.06 \%$ & 1,266 \\
& To 48 & $16.48 \%$ & 1,614 & $3.27 \%$ & 1,497 & $6.36 \%$ & 1,305 \\
& To 52 & $18.56 \%$ & 1,584 & $4.37 \%$ & 1,489 & $5.28 \%$ & 1,307 \\
& To 57 & $19.80 \%$ & 1,586 & $4.67 \%$ & 1,479 & $5.87 \%$ & 1,311 \\
& To 64 & $18.58 \%$ & 1,421 & $5.35 \%$ & 1,326 & $5.17 \%$ & 1,141 \\
& To 99 & $18.93 \%$ & 1,712 & $4.17 \%$ & 1,606 & $3.57 \%$ & 1,400 \\
Total & & $17.92 \%$ & 14,552 & $4.42 \%$ & 13,442 & $6.52 \%$ & 11,687 \\
& & & & & & & \\
Annual hh income & & & & & & \\
under 7.5 & & $10.53 \%$ & 152 & $2.17 \%$ & 138 & $10.34 \%$ & 116 \\
$7.5-15$ & & $11.07 \%$ & 768 & $3.07 \%$ & 685 & $5.08 \%$ & 591 \\
$15-25$ & & $12.32 \%$ & 1,583 & $4.08 \%$ & 1,422 & $7.67 \%$ & 1,213 \\
$25-40$ & & $12.63 \%$ & 4,187 & $3.16 \%$ & 3,803 & $5.82 \%$ & 3,263 \\
$40-60$ & & $13.12 \%$ & 5,715 & $3.97 \%$ & 5,233 & $5.25 \%$ & 4,474 \\
$60-75$ & & $13.78 \%$ & 3,526 & $4.38 \%$ & 3,239 & $6.30 \%$ & 2,762 \\
$75-100$ & & $14.97 \%$ & 2,920 & $4.79 \%$ & 2,695 & $4.46 \%$ & 2,331 \\
$100-150$ & & $15.99 \%$ & 1,801 & $5.05 \%$ & 1,665 & $4.86 \%$ & 1,461 \\
$150+$ & & $14.14 \%$ & 693 & $4.98 \%$ & 642 & $4.25 \%$ & 565 \\
Total & & $13.51 \%$ & 21,345 & $4.08 \%$ & 19,522 & $5.56 \%$ & 16,776 \\
\hline
\end{tabular}


Table 6: II Use and Preference for Branded Retailers

\begin{tabular}{|c|c|c|c|c|c|c|c|c|}
\hline & $(1)$ & (2) & (3) & (4) & $(5)$ & (6) & (7) & (8) \\
\hline Dependent Variable--> & $\begin{array}{c}\text { Amazon/ } \\
\text { Choice Set }\end{array}$ & $\begin{array}{l}\text { Amazon/ } \\
\text { Choice Set }\end{array}$ & $\begin{array}{c}\text { Amazon/ } \\
\text { Choice Set }\end{array}$ & $\begin{array}{c}\text { Amazon/ } \\
\text { Choice Set }\end{array}$ & $\begin{array}{l}\text { Known/ } \\
\text { Choice Set }\end{array}$ & $\begin{array}{l}\text { Known/ } \\
\text { Choice Set }\end{array}$ & $\begin{array}{l}\text { Known/ } \\
\text { Choice Set }\end{array}$ & $\begin{array}{l}\text { Known/ } \\
\text { Choice Set }\end{array}$ \\
\hline II Use Measure -> & II Pages & $\begin{array}{c}\text { Cum. II } \\
\text { Pages } \\
\end{array}$ & $\begin{array}{c}\text { Visit II this } \\
\text { Month }\end{array}$ & $\begin{array}{c}\text { Ever Visit } \\
\text { II? }\end{array}$ & II Pages & $\begin{array}{l}\text { Cum. II } \\
\text { Pages } \\
\end{array}$ & $\begin{array}{l}\text { Visit II this } \\
\text { Month }\end{array}$ & $\begin{array}{l}\text { Ever Visit } \\
\text { II? }\end{array}$ \\
\hline BizRate & $\begin{array}{c}-0.0008 \\
(0.0002)^{* *}\end{array}$ & $\begin{array}{c}-0.0003 \\
(0.0002)^{*}\end{array}$ & $\begin{array}{l}-0.0423 \\
(0.0056) * *\end{array}$ & $\begin{array}{l}-0.0274 \\
(0.0055)^{* *}\end{array}$ & $\begin{array}{c}-0.0008 \\
(0.0003)^{* *}\end{array}$ & $\begin{array}{l}-0.0006 \\
(0.0002) * *\end{array}$ & $\begin{array}{l}-0.0640 \\
(0.0065) * *\end{array}$ & $\begin{array}{l}-0.0533 \\
(0.0064) * *\end{array}$ \\
\hline DealTime & $\begin{array}{l}-0.0007 \\
(0.0006)\end{array}$ & $\begin{array}{l}-0.0001 \\
(0.0004)\end{array}$ & $\begin{array}{l}-0.0427 \\
(0.0140) * *\end{array}$ & $\begin{array}{l}-0.0232 \\
(0.0121)\end{array}$ & $\begin{array}{l}-0.0014 \\
(0.0005)^{* *}\end{array}$ & $\begin{array}{l}-0.0008 \\
(0.0003) * *\end{array}$ & $\begin{array}{l}-0.0953 \\
(0.0114) * *\end{array}$ & $\begin{array}{l}-0.0664 \\
(0.0099)^{* *}\end{array}$ \\
\hline mySimon & $\begin{array}{l}-0.0004 \\
(0.0004)\end{array}$ & $\begin{array}{l}-0.0001 \\
(0.0002)\end{array}$ & $\begin{array}{l}-0.0179 \\
(0.0133)\end{array}$ & $\begin{array}{l}-0.0002 \\
(0.0123)\end{array}$ & $\begin{array}{l}-0.0010 \\
(0.0003)^{* *}\end{array}$ & $\begin{array}{l}-0.0006 \\
(0.0002)^{* *}\end{array}$ & $\begin{array}{l}-0.0536 \\
(0.0128)^{* *}\end{array}$ & $\begin{array}{l}-0.0375 \\
(0.0119) * *\end{array}$ \\
\hline
\end{tabular}

Note: each entry represents a separate regression. The dependent variable for columns (1)-(4) is Amazon pages/pages in the choice set for the row's II. The dependent variable for columns (5)-(8) is page visits to "known" sites/page visits to the choice set for the row's II. The measure of II use is listed above the coefficients in each column. All regressions include individual fixed effects as well as month dummies. Standard errors in parentheses. $*$ significant at $5 \% ; * *$ significant at $1 \%$ 
Table 7: Effects on II Use on Constituent Parts of "Known"

\begin{tabular}{|c|c|c|c|c|c|c|c|c|c|}
\hline & $(1)$ & (2) & (3) & (4) & $(5)$ & (6) & (7) & (8) & $(9)$ \\
\hline & BizRate & BizRate & BizRate & DealTime & DealTime & DealTime & mySimon & mySimon & mySimon \\
\hline Constituent part & $\begin{array}{l}\text { Coef } \\
\text { (s.e.) }\end{array}$ & $\begin{array}{c}\text { Share of } \\
\text { choice set } \\
\text { page visits }\end{array}$ & $(1) /(2)$ & $\begin{array}{l}\text { Coef } \\
\text { (s.e.) }\end{array}$ & $\begin{array}{c}\text { Share of } \\
\text { choice set } \\
\text { page visits }\end{array}$ & $(4) /(5)$ & $\begin{array}{l}\text { Coef } \\
\text { (s.e.) }\end{array}$ & $\begin{array}{c}\text { Share of } \\
\text { choice set } \\
\text { page visits }\end{array}$ & $(7) /(8)$ \\
\hline Amazon & $\begin{array}{c}-0.0423 \\
(0.0056)^{* *}\end{array}$ & 0.22 & $-19.1 \%$ & $\begin{array}{c}-0.0427 \\
(0.0140)^{* *}\end{array}$ & 0.45 & $-9.4 \%$ & $\begin{array}{c}-0.0179 \\
(0.0133)\end{array}$ & 0.32 & $-5.6 \%$ \\
\hline Other known & $\begin{array}{c}0.0036 \\
(0.0051)\end{array}$ & 0.19 & $1.9 \%$ & $\begin{array}{c}-0.0224 \\
(0.0128)\end{array}$ & 0.30 & $-7.4 \%$ & $\begin{array}{c}-0.0145 \\
(0.0116)\end{array}$ & 0.23 & $-6.3 \%$ \\
\hline Offline Chain & $\begin{array}{c}-0.0227 \\
(0.0047)^{* *}\end{array}$ & 0.13 & $-18.0 \%$ & $\begin{array}{c}-0.0043 \\
(0.0048)\end{array}$ & 0.02 & $-18.9 \%$ & $\begin{array}{c}-0.0089 \\
(0.0109)\end{array}$ & 0.14 & $-6.3 \%$ \\
\hline Manufacturer & $\begin{array}{c}-0.0061 \\
(0.0036)\end{array}$ & 0.07 & $-8.2 \%$ & & & & $\begin{array}{c}-0.0043 \\
(0.0053)\end{array}$ & 0.04 & $-11.3 \%$ \\
\hline Catalog & $\begin{array}{c}0.0035 \\
(0.0034)\end{array}$ & 0.08 & $4.6 \%$ & $\begin{array}{c}-0.0260 \\
(0.0066)^{* *}\end{array}$ & 0.04 & $-63.7 \%$ & $\begin{array}{c}-0.0078 \\
(0.0068)\end{array}$ & 0.05 & $-16.7 \%$ \\
\hline Total Known & $\begin{array}{c}-0.0640 \\
(0.0065)^{* *}\end{array}$ & 0.69 & $-9.3 \%$ & $\begin{array}{c}-0.0953 \\
(0.0114)^{* *}\end{array}$ & 0.82 & $-11.6 \%$ & $\begin{array}{c}-0.0536 \\
(0.0128)^{* *}\end{array}$ & 0.77 & $-6.9 \%$ \\
\hline
\end{tabular}

Note: each entry in columns 1,4 , and 7 is from a separate regression, and each entry shows the coefficient on a dummy for whether the individual uses the column's II this month. Dependent variables are the constituent parts of "total known" for the row. All regressions include individual fixed effects and month dummies. Entries in columns 2, 5, and 8 show the share of choice set page visits to the row's constituent element. Columns (3), (6), and (9) show the proportionate reduction in the constituent part of known with II use, calculated as the coefficient divided by the element's share of the choice set. 
Table 8: Robustness Checks on "Visit this Month" Coefficient

\begin{tabular}{|c|c|c|c|c|c|c|c|c|}
\hline Dependent variable $\rightarrow$ & $\begin{array}{c}\text { Amazon/ } \\
\text { Choice Set }\end{array}$ & $\begin{array}{c}\text { Known/ } \\
\text { Choice Set }\end{array}$ & $\begin{array}{l}\text { Amazon/ } \\
\text { MM Retail } \\
\text { (excl } \\
\text { auctions) }\end{array}$ & $\begin{array}{c}\text { Known/ } \\
\text { MM Retail } \\
\text { (excl auctions }\end{array}$ & $\begin{array}{l}\text { Amazon/ } \\
\text { MM Retail } \\
\text { (incl } \\
\text { auctions) }\end{array}$ & $\begin{array}{c}\text { Known/ } \\
\text { MM Retail } \\
\text { (incl auctions }\end{array}$ & $\begin{array}{c}\text { Amazon/ } \\
\text { Choice Set }\end{array}$ & $\begin{array}{c}\text { Known/ } \\
\text { Choice Set }\end{array}$ \\
\hline Visit BizRate this Month & $\begin{array}{c}-0.0353 \\
(0.0060)^{* *}\end{array}$ & $\begin{array}{c}-0.0508 \\
(0.0070)^{* *}\end{array}$ & $\begin{array}{c}-0.0182 \\
(0.0033)^{* *}\end{array}$ & $\begin{array}{c}-0.0018 \\
(0.0051)\end{array}$ & $\begin{array}{c}-0.0140 \\
(0.0031)^{* *}\end{array}$ & $\begin{array}{c}0.0038 \\
(0.0048)\end{array}$ & $\begin{array}{c}-0.0432 \\
(0.0056)^{* *}\end{array}$ & $\begin{array}{c}-0.0666 \\
(0.0066)^{* *}\end{array}$ \\
\hline $\mathrm{N}$ & 79288 & 79288 & 145124 & 145124 & 148310 & 148310 & 101710 & 101710 \\
\hline Visit DealTime this Month & $\begin{array}{c}-0.0304 \\
(0.0147)^{*}\end{array}$ & $\begin{array}{c}-0.0656 \\
(0.0121)^{* *}\end{array}$ & $\begin{array}{l}-0.0071 \\
(0.0062)\end{array}$ & $\begin{array}{c}-0.0193 \\
(0.0077)^{*}\end{array}$ & $\begin{array}{l}-0.0065 \\
(0.0058)\end{array}$ & $\begin{array}{c}-0.0159 \\
(0.0072)^{*}\end{array}$ & $\begin{array}{c}-0.0380 \\
(0.0141)^{* *}\end{array}$ & $\begin{array}{c}-0.0915 \\
(0.0114)^{* *}\end{array}$ \\
\hline $\mathrm{N}$ & 48445 & 48445 & 145306 & 145306 & 148310 & 148310 & 67651 & 67651 \\
\hline Visit mySimon this Month & $\begin{array}{c}-0.0110 \\
(0.0144) \\
63182\end{array}$ & $\begin{array}{c}-0.0429 \\
(0.0139)^{* *} \\
63182\end{array}$ & $\begin{array}{c}-0.0016 \\
(0.0069) \\
145306\end{array}$ & $\begin{array}{c}0.0042 \\
(0.0098) \\
145306\end{array}$ & $\begin{array}{c}0.0008 \\
(0.0065) \\
148310\end{array}$ & $\begin{array}{c}0.0030 \\
(0.0092) \\
148310\end{array}$ & $\begin{array}{c}-0.0171 \\
(0.0133) \\
84219\end{array}$ & $\begin{array}{c}-0.0530 \\
(0.0128) * * \\
84219\end{array}$ \\
\hline Features of specification $\rightarrow$ & $\begin{array}{c}\text { Correction for } \\
\text { autocorrelated } \\
\text { errors }\end{array}$ & $\begin{array}{l}\text { Correction for } \\
\text { autocorrelated } \\
\text { errors }\end{array}$ & $\begin{array}{c}\text { Denominator } \\
=\text { MM Retail } \\
\text { (excl auctions) }\end{array}$ & $\begin{array}{l}\text { Denominator } \\
=\mathrm{MM} \text { Retail } \\
\text { (excl auctions) }\end{array}$ & $\begin{array}{l}\text { Denominator } \\
=\text { MM Retail } \\
\text { (incl auctions) }\end{array}$ & $\begin{array}{l}\text { Denominator } \\
=\text { MM Retail } \\
\text { (incl auctions) }\end{array}$ & $\begin{array}{l}\text { Includes } \\
\text { control for } \\
\text { total retail } \\
\text { pages (excl } \\
\text { auctions) }\end{array}$ & $\begin{array}{c}\text { Includes } \\
\text { control for } \\
\text { total retail } \\
\text { pages (excl } \\
\text { auctions) }\end{array}$ \\
\hline
\end{tabular}

Notes: All specifications include individual fixed effects and month effects. 